\section{B A Institute of \\ YK Business Administration \\ 六下 \\ Karachi \\ Leadership and Ideas for Tomorrow}

Business Review

Volume 11 Issue 1 January-June 2016

$1-1-2016$

\title{
Exploring the factors influencing faculty motivation and satisfaction in tertiary education
}

Zaki Rashidi

Management Science Department, SZABIST, Karachi, Pakistan

Sajida Zaki

Humanities Department, NEDUET, Karachi, Pakistan

Amanat Ali Jalbani

International Technology University, San Jose, CA, USA

Follow this and additional works at: https://ir.iba.edu.pk/businessreview

Part of the Economics Commons

\section{c) (7)}

This work is licensed under a Creative Commons Attribution 4.0 International License.

\section{Recommended Citation}

Rashidi, Z., Zaki, S., \& Jalbani, A. A. (2016). Exploring the factors influencing faculty motivation and satisfaction in tertiary education. Business Review, 11(1), 10-26. Retrieved from https://doi.org/10.54784/ 1990-6587.1074

This article is brought to you by iRepository for open access under the Creative Commons Attribution 4.0 License and is available at https://ir.iba.edu.pk/businessreview/vol11/iss1/2. For more information, please contact irepository@iba.edu.pk. 


\title{
ARTICLE
}

\section{Exploring the Factors Influencing Faculty Motivation and Satisfaction in Tertiary Education}

\author{
Zaki Rashidi \\ Management Science Department, SZABIST, Karachi, Pakistan \\ Sajida Zaki \\ Humanities Department, NEDUET, Karachi, Pakistan \\ Amanat Ali Jalbani \\ International Technology University, San Jose, CA, USA
}

\begin{abstract}
This study examines the importance of the following five factors in determining motivation and satisfaction levels among faculty involved in higher education: compensation, job role and responsibilities, organizational environment, career growth and recognition. Relevant data were collected from a survey of faculty based at professional universities in Pakistan. Results show that while all five chosen factors are significantly correlated with faculty motivation and satisfaction levels, compensation and recognition are the two most important determinants.
\end{abstract}

Key Words: Faculty motivation, job satisfaction, compensation, higher education

\section{Introduction}

Higher education in Pakistan has undergone many reforms in recent years and various new policies are being implemented at tertiary level education to promote and inculcate research and development culture among university faculty and students. These policies, directly or indirectly, are affecting work dynamics and behavior of faculty members in universities (Khalid, Irshad, \& Mahmood, 2012; Mahmood \& Shafique, 2010). The positive aspects of these policies are: improved compensation packages, enhanced resources, and better work environment, whereas the negative aspects can be stagnant promotions, sluggish career growth, and work pressures. Some faculty members are taking these policies as a threat to their career growth while others perceive them as an opportunity to rapid career advancement (Aziz, Khan, \& Aziz, 2008). One of the most significant factors affected by these policies is the motivation of faculty members. It plays a pivotal role in imparting quality education and in turn enhances learning of the students in professional universities. Therefore, higher education institutions always emphasize at congenial learning environment through vibrant academic culture. The commitment of a faculty member is directly related to job satisfaction, job security, compensation, appreciation, empowerment and respect in society (Castillo \& Canoe, 2004; Khalid, Irshad, \& Mahmood, 2012).

The current study is intended to investigate the level of motivation and job satisfaction of the faculty members in public and private sector professional universities of Pakistan. Various studies were conducted in past to investigate different aspects related to higher education in Pakistan (e.g. Aziz \& Akhtar, 2014; Aziz, Khan \& Aziz, 2008; Irshad \& Mahmood, 2012; Mahmood \& Shafique, 2010) but very few studies are related to identification of factors that influence the motivation and job satisfaction of higher education faculty members (Okafor, 2014). This study identifies significant and contributing factors 
towards job satisfaction and motivation. The study further tests these factors that are affecting the motivation of university teachers and differentiates the significant factors in public and private sector universities. Primary investigation is done to probe motivation level through factors like: compensation package, job roles and responsibilities, work environment, and career development. The aim of this research is to determine the impact of significant factors - compensation, environment, job role and responsibilities, career growth and recognition on higher education faculty motivation and job satisfaction, also the interplay if there was a pattern or trend with respect to the nature of organization and gender.

\section{Literature Review}

Globalization brought many pressures to twenty-first century organizations where managers are not only enhancing the human resource competencies but also working to satisfy, motivate and retain the existing valuable human asset of their organizations (Cooke, Saini \& Wang, 2014). One of the biggest challenges in today's workplace is the motivation of employees to enhance productivity and assure sustainability (Blok, Wesselink, Studynka, \& Kemp, 2014). Motivation is defined as the process that accounts for an individual's intensity, direction and persistence of efforts towards attaining a goal (Dornyei \& Ushioda, 2013; Pinder, 2014). Motivation can be intrinsic or extrinsic. Deci's model of intrinsic and extrinsic motivators (Ryan \& Deci, 2012) proposed that individuals are motivated by drives for competence and self determination or autonomy. Over the years, several different theories about motivation have been proposed and tested. Most of these theories can be categorized into two basic types: process theories and content theories (Petri \& Govern, 2012). Lunenberg (2011) describes that process theories of motivation are explanations that emphasize how individuals are motivated; whereas content theories are explanations that emphasize internal characteristics. Therefore, organizations are studying motivation at different levels for their survival (Kim, 2012; Smith, 1994), and motivated employees are needed in rapidly changing workplace (Carleton, 2011; Lindner 1998). In fact, the famous Hawthorne Studies began the human relations approach to management, whereby the needs and motivation of employees become the primary focus of managers (Bedeian, 1993; Danish \& Usman, 2010).

There are various factors that can be instrumental in motivating the employees of any organization, and the relative degrees in which these factors influence a person also vary from one individual to the other (Kabir \& Parvin, 2011). A number of research studies emphasize culture (Aycan 2001), empowerment (Conger \& Kanungo, 1987), psychology of work force (Brislin et al. 2005); while others accentuate interesting work, good wages, and job security (Harpaz, 1990). Brislin et al. (2005) argue that managers must understand the culture and psychology of their work force which will have an impact on their motivational strategy (Trumbull \& Rothstein-Fisch, 2011). For example, if one is managing a work force that greatly values 'quality of life' such as leisure time, time with family etc., then attempting to increase motivation level of such a group through an increase in pay might prove insignificant (Sekar \& Narayanan, 2006).

There are several definitions of motivation in psychology that stresses on different aspects; however, the consensus of majority of these definitions can be summarized as motivation is an internal state or condition that serves to activate or energize behavior of a person and give it direction (Lang, 2010). Hence from this definition we can drive work place motivation as the willingness to exert high levels of effort toward organizational goals, conditioned by the efforts' ability to satisfy some individual need (Pinder, 2014). There are three key elements in this definition: effort, organizational goals and needs. A need means some internal state that makes certain outcomes appear attractive. An unsatisfied need creates tension and that stimulates drives within the individual (Pinder, 2014; Robbins, 2003). These 
drives generate a search behavior to find particular goals, if attained will satisfy the needs and reduce the tension; and if not attained increases the tension and results in frustration (Kabir \& Parvin, 2011).

Most motivation theorists assume that motivation is involved in the performance of all learned responses; that is, a learned behavior will not occur unless it is energized (Dornyei \& Ushioda, 2013). The major question among psychologists in general, is whether motivation is a primary or secondary influence on behavior. Which means changes in behavior better can be explained by principles of environmental or ecological influences, perception, memory, cognitive development, emotion, explanatory style, or personality or are concepts unique to motivation more pertinent (Ryan \& Deci, 2012).

Motivation is important because it explains why employees in an organization behave as they do and most importantly why they do it. Work motivation can also be characterized as, "the psychological forces within a person that determine the direction of a person's behavior in an organization, a person's level of effort and person level of persistence, in the face of obstacles" (Lammers, 2009, p.128) The characteristic direction of behavior is the behavior a person selects, positive or negative, to achieve organizational objectives: Level of efforts is that how hard a person tries the selected behavior to achieve the desired goal; whereas level of persistence is continuity and consistency of behavior (Pinder, 2014; Ryan \& Deci, 2012).

The motivation of a person can be classified into two broad categories i.e. intrinsic motivation and extrinsic motivation (Wise, 2004). Intrinsic motivation is defined as the doing of an activity for its inherent satisfactions rather than for some separable consequences. When intrinsically motivated employee is moved to act for the fun or challenge entailed rather than because of external prods, pressures, or rewards (Gibson et al., 2004; Pinder, 2014). In contrast extrinsic motivation is a construct that pertains whenever an activity is done in order to attain some separable outcome i.e. money, designation, or simply praise. Extrinsic motivation thus differs from intrinsic motivation, which refers to doing an activity simply for the enjoyment of the activity itself, rather than its instrumental value (Thomas \& Velthouse, 1990). For example, an employee is completing an assignment because it is known that failing in completing the assignment as per deadline will result either monetary loss or may debar from some future benefits. Even an employee who is working keeping in mind the future promotions is extrinsically motivated because some instrumental value, not necessarily achieved in near future, is attached with this behavior. Hence, intrinsic motivation is to satisfy one's inner self while extrinsic motivation is the behavior performed to acquire material or social rewards or to avoid punishment (Petri \& Govern, 2012).

Teachers, especially in higher education, are different as professionals and knowledge workers from other professional and blue collar workers (Bishey, 1996; Bowen, \& Radhakrishna, 1991) as they have a strong and long-term commitment to their field and for them challenging task, support to implement their innovative ideas, trainings, participation in workshop and conferences are more important than the other factors (Robbins, 2003). Sylvia \& Hutchinson (1985) concluded through a study of teachers' motivation that, "Teacher motivation is based in the freedom to try new ideas, achievement of appropriate responsibility levels, and intrinsic work element (p.855)." They believe in freedom of work and empowermen: Empowerment, which is defined as worker's feeling of competence (Conger \& Kanungo, 1988), is a concept that is sometimes used in conjunction with intrinsic motivation. Empowered employees take responsibility for accomplishing their tasks and are less inclined to bureaucratic procedures and managerial direction (Thomas \& Velthouse, 1990). 
Motivation is a fundamental aspect of leveraging human performance (Pinder, 2014), it is considered the corner stone by the industrial psychologists and human resource managers (Steer, Mondays, Shapiro, 2004). According to Watson (2008) it is the prime problem to motivate the employees on a continuous basis. The understanding of motivation and using it for employees' performance is complex in nature because it is confounded by many other factors, but for practical reasons it can be subdivided into intrinsic extrinsic motivation (Pinder, 2011). However, Kanfer et al. (2008) posited that the role of motivation is to provide direction and intensity to enhance the performance. Employee motivation is a complex phenomenon and it has many antecedents and consequences (Wise, 2004). Many studies examined the role of extrinsic motivation in explaining performance (Ryan \& Deci, 2000), job satisfaction (Stringer, Didham \& Theivananthampillai, 2011), job satisfaction and commitment (Pepe, 2010), individual knowledge sharing (Hung, Druckikova, Lai, \& Lin, 2011), turnover intention (Dysvik \& Kuvaas, 2010), task performance (Rogstadius, 2011; Cerasoli \& ford, 2014), and organizational citizenship behavior (Finkelstein, 2011). But their interactive impact is yet to be explained in various contexts (Cerasoli, Nicklin, \& Ford, 2014). Another explanation of motivation is "[...] an accumulation of different processes which influence and direct our behavior to achieve some specific goals" (Baron, 1983, p.123). Motivation contains, "those psychological processes that cause the arousal direction, and persistence of voluntary action that are goal directed" and "motivation is concerned with action and the internal and external forces that influence one's choice of action. Motivation is not the behavior itself and it is not performance" (Mitchell, 1982, pp. 81-82).

Motivation is directly connected to another important construct i.e. satisfaction. Employee satisfaction is different from motivation. A satisfied employee is not necessarily is a motivated employee and vice versa (Castillo \& Canoe, 2004). However, there is a strong relationship between employee motivation and satisfaction (Gillet, Valherand, \& Rosenet, 2009; Inder, 2014; Stringer, 2011). One of the major functions of today's managers in the organization is to motivate their employees and achieve greater organizational efficiency (Oosthuizen, 2011). Performance of an employee is directly linked with their motivational factors (Entiwistle,1987). It is argued that organizational commitment and reward are interconnected. A balance between reward and recognition of employee results in better organizational performance (Lawler, 2003). Gibson et al. (2000) considered motivation as a concept when someone experiences the forces that direct the behavior of an individual. It not only directs but energizes but sustained the effort to achieve the set goals (Snell, 1999).

Unwen (2000) views employee motivation as a process that channelizes the energies and harmonizes them to lead towards consistent efforts to achieve the set goals. Even employees can forgo their personal goals to achieve organizational objectives (Gasva, Moyo, Chisango, 2015). "Work motivation is, therefore, a set of energetic forces that originates both within as well as beyond an individual's being, to initiate work related behavior, and determine its forms, direction, intensity, and duration." (Pinder, 2008, p. 11). Gibson et al. (2000) explicated that job satisfaction is "an individual's expression of personal wellbeing associated with doing the job assigned." Green (2000) has identified a positive relationship between rewards and motivation. Spector (1985) posited that job satisfaction is that how do people feel about the nature of their job and related to various aspects of it. This notion is also supported by Ellickson and Logsdon (2002) that the job satisfaction is actually that how much an employee likes the work. The psychological aspect of job satisfaction can be related to the affective and emotional response towards various aspects of one's job. It is further expanded as feeling towards work, attitude towards the job, perception regarding the importance of one's work, need fulfilment and aggregated affective and emotional response towards the feelings of one's work (Reilly, 1991). Job satisfaction depends on one's expectation towards 
the job (Hussami, 2008). Higher organizational rewards increase job satisfaction (Willem et al., 2007).Job satisfaction is influenced by many other factors like autonomy, communication, and commitment along with pay packages and benefits (Lane, Esser, Holte \& Anne, 2010; Vidal, Valle \& Argon, 2007; Xie \& Johns, 2000).It has been found that different individuals display different motivational profile even within the same situation or activity (Gillet, Vallerand \& Rosnet, 2009; Vansteenkieste, Sierens, Soenens, Luyckx \& 2009).

Drawing on the earlier works carried out on the factors governing employee motivation and satisfaction, current study has identified five factors' framework to leverage motivation and satisfaction, i.e. compensation package (pay, monetary benefits), environment (safety, security, culture), job responsibilities and roles (work interest, empowerment, freedom to implement new ideas), career growth (promotions and future prospects), and recognition (acknowledgement of efforts and endeavors).

\section{Research Methodology}

This research is quantitative in nature, and based on post-positivist paradigm and deductive in nature. The primary data is collected by using a survey, conducted in public and private universities through cross-sectional approach.

\section{Participant Selection}

The population of the study comprises professional universities in Pakistan. The inclusion and exclusion criteria of selection of units were based on that the university must have sufficiently large number of faculty members available to be true representative of the population. Lab assistants, lab engineers, and teaching assistants are not included in this survey. Even visiting faculty members associated with the university are not treated as faculty members. Only full time teachers who are on the payroll of the university and are directly involved in teaching in the classroom, administration, and research participated in the survey. The sampling method was based on self selection sampling; only those faculty members were contacted who agreed to provide the data and willing to furnish written feedback on the prescribed form. A prior verbal permission was taken by the concerned authorities or administration of the university to conduct the anonymous survey.

\section{Questionnaire Development}

The questionnaire is based on seven constructs: (1) compensation, (2) job role and responsibilities, (3) environment, (4) career growth, (5) recognition, (6) job satisfaction, and (7) motivation. All constructs have 4 items, with total 28 items. Items were both selfdeveloped and adapted from the different studies by the researcher, and before conducting actual study a pilot study was conducted which resulted Cronbach alpha (.723), and all the constructs have the value of alpha above (0.67), therefore the scale is considered reliable. Face and content validity of the scale was evaluated by the faculty members prior to collecting the data and some items were revised in terms of language, clarity of meaning, and duplication. Along with the seven constructs profile questions are also appended in the final questionnaire. The questionnaire was administered through contact persons and enumerators in different universities. In exploratory factor analysis although some items had cross loadings but items were placed on the basis of expert judgment in a given construct.

\section{Data Analysis and Discussion}

After collecting the data, it is condensed on the basis of subscales and variables; and analysis is performed to investigate the relationship among these factors. A further analysis is applied by using hierarchical regression analysis to test the relationship of job satisfaction and 
motivation with other five subscales. The analysis is also performed in partitioned data like, on the basis of gender, professional qualification, experience, and association with the university. Total 1200 forms were distributed among both public and private professional universities. Out of which 907 forms were returned; after careful scrutiny 27 incomplete forms were rejected that leaves total 880 usable forms with a response rate of $73.33 \%$. The sample size of 880 is sufficient to run step-wise multiple regression analysis because the variable to case ratio becomes is approximately 1:125. No influential observations are found in the data.

The profile of the respondents shows that both male and female faculty participated in the survey with almost equal participation of both public and private sector universities. The sample is skewed with lectures and assistant professors, therefore the interpretations of the results would be mostly true for junior and mid career faculty members. The complete profile of the respondents is given below in table 1 .

Table 1: Frequency and Percentage of Respondents Profile

\begin{tabular}{|c|c|c|c|}
\hline \multirow{3}{*}{ Gender } & & Frequency & Percent \\
\hline \multirow{3}{*}{ University Type } & Male & 574 & 65.22 \\
\cline { 2 - 4 } & Female & 306 & 34.78 \\
\cline { 2 - 4 } & Public & 413 & 46.93 \\
\hline \multirow{3}{*}{ Designation } & Private & 467 & 53.07 \\
\cline { 2 - 4 } & Lecturer & 467 & 53.07 \\
\cline { 2 - 4 } & Assistant Professor & 293 & 33.29 \\
\cline { 2 - 4 } & Associate Professor & 87 & 9.89 \\
\cline { 2 - 4 } & Professor & 33 & 3.75 \\
\hline \multirow{3}{*}{ Experience } & $1-5$ years & 376 & 42.73 \\
\cline { 2 - 4 } & $6-10$ years & 239 & 27.16 \\
\cline { 2 - 4 } & $11-15$ years & 208 & 23.64 \\
\cline { 2 - 4 } & above 15 years & 57 & 6.47 \\
\hline \multirow{3}{*}{ Marital Status } & Married & 479 & 54.43 \\
\cline { 2 - 4 } & Unmarried & 401 & 45.57 \\
\hline
\end{tabular}

The questionnaire was based on seven constructs besides profile questions. Each construct consists of 4 items on a Likert scale, which were coded as strongly disagree $=-2$, neutral $=0$, and strongly agree $=2$. The reliability of the scale by using Cronbach alpha was found to be .806 (28 items); and reliability of each construct (four items each) was above 0.71 .

The descriptive analysis of the constructs shows that except compensation all the means are positive, i.e. faculty members are more towards disagreement on the given scale. Whereas motivation level is higher than the satisfaction level; however, motivation has higher standard deviation as well, which means motivation of faculty has higher spread. All the correlations are found to be significant at .01 level of significant. The compensation is highly correlated with both faculty motivation and satisfaction; while satisfaction is highly correlated with career growth and recognition and motivation is highly correlated with environment. All the correlations are sufficiently high (see table 2). 
Table 2: Descriptive Analysis and Correlation of the Constructs

\begin{tabular}{|c|c|c|c|c|c|c|c|c|c|}
\hline Construct & Mean & SD & Comp & Job & Env & Career & Recog & Sat & Mot \\
\hline $\begin{array}{c}\text { Compen } \\
\text { sation }\end{array}$ & $\begin{array}{c}- \\
.0597\end{array}$ & 1.10054 & 1 & & & & & & \\
\hline Job Role & .6875 & 1.04857 & $.375^{* *}$ & 1 & & & & & \\
\hline Environment & .6332 & 1.09469 & $.427^{* *}$ & $.598^{* *}$ & 1 & & & & \\
\hline $\begin{array}{c}\text { Career } \\
\text { Growth }\end{array}$ & .3707 & 1.06573 & $.532^{* *}$ & $.393^{* *}$ & $.539^{* *}$ & 1 & & & \\
\hline Recognition & .4432 & 1.07594 & $.484^{* *}$ & $.557^{* *}$ & $.654^{* *}$ & $.562^{* *}$ & 1 & & \\
\hline Satisfaction & .3210 & .98913 & $.849^{* *}$ & $.443^{* *}$ & $.536^{* *}$ & $.740^{* *}$ & $.610^{* *}$ & 1 & \\
\hline Motivation & .7273 & 1.04472 & $.665^{* *}$ & $.446^{* *}$ & $.620^{* *}$ & $.591^{* *}$ & $.641^{* *}$ & $.813^{* *}$ & 1 \\
\hline
\end{tabular}

* Significant at .01

The presence of high correlation of independent variables (compensation, job role, environment, career growth, recognition) with the dependent variables (motivation and satisfaction) may affect the ordinary least square; therefore, step-wise multiple regression analysis is applied.

First, hierarchical regression analysis is applied to test the factors affecting faculty motivation as dependent variable; and compensation, job role, environment, career growth, and recognition as independent variable (see Appendix Table A1). In figure 1A (see appendix) the normal p-p plot of regression standardized residuals is almost normal. The model summary shows that Durbin Watson value as 2.039 which is close to 2, therefore there is no autocorrelation in the observations, which is also evident from the cross-sectional data (see Appendix Table A2). The model summary also suggests that the final model (model 3) has the value of adjusted R-square as .602 ( $p=.007)$, hence the dependent variable motivation is well explained by compensation package, environment, and recognition. The ANOVA of the model (see Appendix Table A3) is significant $(p=.000)$ for all the three predictors.

The coefficients matrix (see Appendix Table A4) reveals that the variable 'compensation' has higher explanatory power to explain motivation of the faculty member with standardized value of .425 , and then other two factors environment and recognition with standardized coefficients .269 and .259 respectively. Interestingly, the remaining two factors i.e. job roles and responsibilities and career opportunities are not explaining the motivation although these factors are moderately correlated with motivation. The Tolerance of all factors is less than 1 or VIF values are close to 2, this suggests that multicollinearity exist in the data; therefore, hierarchical regression results are may suffer while using these coefficients as predictor of motivations. For this reason, standardized coefficients are reported for explanation of the variables (Hair et al, 2015). In coefficients table the part and partial correlations are also much lower than the zero order correlations. The excluded variables by stepwise regression analysis i.e. job role and career growth are insignificant with $p$-values .724 and .145 respectively.

Second stepwise regression analysis is applied for satisfaction by taking again compensation, job role, environment, career growth, recognition as independent variables. The method used is step-wise with criteria: probability of $\mathrm{F}$ to enter $<.050$ and probability of $\mathrm{F}$ to remove $>.100$ (see Appendix Table B1). According to figure 1B (see appendix) the normal p-p plot of regression standardized residuals is approximately normal. The model summary shows that Durbin Watson value as 1.85 which can be considered as no 
autocorrelation in the observations due to cross-sectional data (see Appendix Table B2). The model summary also suggests that the final model (model 3) has the value of adjusted Rsquare as $.840(p=.027)$, hence the dependent variable satisfaction is well explained by compensation package, career growth, and recognition. This is in contrast to the results of motivation, where the factor of environment was significant and entered into the model instead of career growth.

The ANOVA of the model (see Appendix Table B3) is significant $(p=.000$ ) for all the three predictors. The coefficients matrix (see Appendix Table B4) reveals that compensation package has once again higher explanatory power to explain satisfaction of the faculty members with standardized value of .603 , and then other two factors career growth and recognition with standardized coefficients .351 and .121 respectively. Similarly to the case of motivation, the remaining two factors i.e. job roles and responsibilities and environment are not explaining the satisfaction although these factors are moderately correlated with satisfaction. The Tolerance of all factors is again less than 1 or VIF values are close to 2, this suggests that multicollinearity exists in the data; therefore hierarchical regression results may suffer while using these coefficients as predictor of satisfaction. For this reason standardized coefficients are reported for explanation of the variables (Hair et al, 2015). In coefficients table the part and partial correlations are also much lower than the zero order correlations. The excluded variables by stepwise regression analysis i.e. job role and environment are insignificant with $p$-values .750 and .754 respectively.

Further analysis reveals that private university faculty members are more motivated than public sector faculty members; and female members are more motivated than satisfied with their jobs as compared to their counterpart males. Four of the five factors compensation package, environment, career growth, and recognition play a significant role in job satisfaction and overall motivation of the faculty members. Those who are more satisfied with their job are more motivated towards work.

The commonality among both the analyses is that compensation package is the most important factor in explaining both the motivation and satisfaction of the faculty members associated with tertiary education and then the recognition. However, to enhance the motivation - environment plays a vital role whereas, career growth is essential for satisfaction of the faculty irrespective of public and private university and gender. The findings of this study are in sync with the existing literature (Ryan \& Deci, 2000, 2012). The factors explaining the motivation in this study are also ascertained by Harpaz (1990) that faculty members are motivated by the good work and pay and security; and Wise (2004) that extrinsic motivation factors are more important to explain the motivation of the faculty which are in our case the compensation package, environment, and recognition (Petri \& Govern, 2012). However, the results or not supporting the studies of Sylvia \& Hutchinson that motivation is more explained by roles and responsibility and intrinsic work elements, and are not aligned with Oosthuizen (2011) and Thomas and Velthouse (1990).

The results of job satisfaction are quite similar to the studies conducted earlier e.g. Lawler (2003) that satisfaction, organizational commitment is linked with reward and recognition, Green (2000) has also ascertained the positive relationship between reward, motivation and satisfaction; and higher organizational rewards enhances the satisfaction of the employees (Willem et al., 2007). Many other studies (e.g. Lane et al., 2010; Vidal, Valle \& Argon, 2007; and Xi \& Johns, 2000) have also reported the results similar to this study that pay package and employee benefits are more important factors in explaining the motivation and satisfaction of the employees. 


\section{Conclusion}

The study has investigated the factors affecting employee motivation and satisfaction of the faculty members associated with higher education institutions. Through the literature five factors were selected on the basis of relevance and importance i.e. compensation, recognition, environment, job role and responsibilities, and career growth. Different factors are identified as to motivate and satisfy the faculty members with two common factors that are compensation and recognition. In many public and private sector universities, although compensation packages are fixed on the basis of designation that are related to grade or scale in which a faculty member is placed, but still other fringe benefits may be introduced to make these packages more attractive for the faculty members. Another factor which is often neglected and can be easily catered by the top management of the university is the recognition. If the efforts and endeavors of a faculty member are duly acknowledged then both motivation and satisfaction of that faculty member can be leveraged to boost the productivity, engagement, and commitment.

It is recommended that there should be programs and policies for the university faculty to recognize their work at different levels by providing them more congenial environment according to their job role and responsibilities. The environment plays an important role towards motivation, hence more resources should be mobilized to cater the needs of the faculty a proper career plan should be given so that a faculty must not be disillusioned in the midst of their career, and a progressive career path must be given to the new incumbents to work with satisfaction and long term commitment.

\section{References}

AL-Hussami M (2008). A Study of nurses' job satisfaction: The relationship to organizational commitment, perceived organizational support, transactional leadership, transformational leadership, and level of education. European Journal of Scientific Research, 22(2), 286-295.

Aziz, B., Khan, T., \& Aziz, S. (2008). Impact of higher education on economic growth of Pakistan. MPRA Paper.

Aziz, F., \& Akhtar, M. M. S. (2014). Impact of Training on Teachers Competencies at Higher Education Level in Pakistan. Researchers World, 5(1), 121.

Aycan Z. (2001). Whatever happened to individual-level studies of work motivation? Crosscultural Psychology Bulletin, 35(2), 7 - 13.

Baron, R. A. (1983). Behaviour in organisations, New York: Allyn \& Bacon, Inc.

Bedeian, A. G. (1993). Management (3 ${ }^{\text {rd }}$ ed.) New York: Dryden Press.

Bishey, A. (1996). Teacher motivation and job satisfaction: A study employing the experience sampling method, Journal of Undergraduate Sciences, 3, 147 - 154.

Bowen, B. E., \& Radhakrishna, R. B. (1991). Job Satisfaction of Agricultural Education Faculty: A Constant Phenomena. Journal of Agricultural Education, 32(2), 16-22.

Blok, V., Wesselink, R., Studynka, O., \& Kemp, R. (2014). Encouraging sustainability in the workplace: a survey on the pro-environmental behavior of university employees. Journal of Cleaner Production. 51, 23 - 33.

Brislin, R. W., MacNab, B., Worthley, R., Kabigting, F., \& Zukis, B. (2005). Evolving Perceptions of Japanese Workplace Motivation an Employee-Manager Comparison. International Journal of Cross Cultural Management, 5(1), 87-104. 
Carleton, K. (2011). How to motivate and retain knowledge workers in organizations: A review of the literature. International Journal of Management, 28(2), 459.

Castillo, J.X.\& Canoe, J. (2004). Factors explaining job satisfaction among faculty, Journal of Agricultural Education, 45(3), 65 - 74.

Cerasoli, C. P., Nicklin, J. M., \& Ford, M. T. (2014). Intrinsic motivation and extrinsic incentives jointly predict performance: A 40-year meta-analysis. Psychological Bulletin, 140(4), 980.

Conger, J. A.\& Kanungo, R. N. (1987). Toward a behavioral theory of charismatic leadership in organizational settings, Academy of Management Review,12, 637 - 647.

Cooke, F. L., Saini, D. S., \& Wang, J. (2014). Talent management in China and India: A comparison of management perceptions and human resource practices. Journal of World Business, 49(2), 225-235.

Danish, R. Q., \& Usman, A. (2010). Impact of reward and recognition on job satisfaction and motivation: An empirical study from Pakistan. International journal of business and management, 5(2), p159.

Deeprose, D. (1994). How to recognize and reward employees? New York: AMACOM

Dörnyei, Z., \& Ushioda, E. (2013). Teaching and researching: Motivation. Routledge.

Dysvik, A., \& Kuvaas, B. (2010). Exploring the relative and combined influence of masteryapproach goals and work intrinsic motivation on employee turnover intention. Personnel review, 39(5), 622-638.

Ellickson, M. C., \& Logsdon, K. (2002). Determinants of job satisfaction of municipal government employees. Public Personnel Management, 31(3), 343-358.

Entwistle, N. (1987). Motivation to learn, conceptualization and practices, British Journal of Education Studies, 35(2), 129-148.

Finkelstein, M. A. (2011). Intrinsic and extrinsic motivation and organizational citizenship behavior: A functional approach to organizational citizenship behavior. Journal of Psychological Issues in Organizational Culture, 2(1), 19-34.

Gasva, D., Mubika, A. K., \& Goronga, Z., S. (2012). Psychological Perspectives in Education: Module BEDM410: Harare. Zimbabwe Open University.

Gibson, J. L., Ivancevich, J. M., Donnelly, J. \& James H. (2000). Organizations, Behavior, Structure and Processes, Boston: McGraw-Hill.

Gillet, N., Vallerand, R. J., \& Rosnet, E. (2009). Motivational clusters and performance in a real-life setting, Motivation and Emotion, 33, 49-62.

Green, T. (2000). Human Resource Magazine, Alexandria, 45(11), 155.

Hackman, J. R.\& Oldham, G. R. (1980). Work redesign, Reading, Addison-Wesley: New York.

Harpaz, I. (1990). The importance of work goals: an international perspective, Journal of International Business Studies, 21, 75 - 93. 
Hung, S. Y., Durcikova, A., Lai, H. M., \& Lin, W. M. (2011). The influence of intrinsic and extrinsic motivation on individuals' knowledge sharing behavior. International Journal of Human-Computer Studies, 69(6), 415-427.

Kanfer, R., Chen, G., \& Pritchard R. (2008). Work motivation: Forging new perspectives and directions in the post-millennium, 601-632. In Kanfer R., Chen G., Pritchard R. D. (Eds.), Work motivation: Past, present, and future, New York: Routledge.

Kabir, M. N., \& Parvin, M. M. (2011). Factors affecting employee job satisfaction of pharmaceutical sector. Australian Journal of Business and Management Research, 1(9), 113123.

Khalid, S., Irshad, M. Z., \& Mahmood, B. (2012). Job satisfaction among academic staff: A comparative analysis between public and private sector universities of Punjab, Pakistan. International Journal of Business and Management, 7(1), p126.

Kim, S. (2012). Does Person-Organization Fit Matter in the Public-Sector? Testing the Mediating Effect of Person-Organization Fit in the Relationship between Public Service Motivation and Work Attitudes. Public Administration Review, 72(6), 830-840.

Lammers, J. (2009). The human factor in knowledge management for development: using theories from social psychology to investigate the predictors of knowledge behavior in development organizations. Knowledge Management for Development Journal, 5(2), 127 142.

Lane, K. A., Esser, J., Holte, B., \& McCusker, M. A. (2010). A study of nurse faculty job satisfaction in community colleges in Florida, Teaching and Learning in Nursing, 5, 16-26.

Lang, P. J. (2010). Emotion and motivation: Toward consensus definitions and a common research purpose. Emotion Review.

Lawler, E. E. (2003). Treat people right. San Francisco: Jossey-Bass Inc. McGraw-Hill Irwin.

Lindner, J. R. (1998). Understanding employee motivation. Journal of extension, 36(3), 1-8.

Lunenburg, F. C. (2011). Expectancy theory of motivation: motivating by altering expectations. International Journal of management, business, and administration, 15(1), 1-6.

Mahmood, K., \& Shafique, F. (2010). Changing research scenario in Pakistan and demand for research qualified LIS professionals. Library Review, 59(4), 291-303.

Oosthuizen, T. F .J. (2001). Motivation influencing worker performance in a technical division of Telkom SA, Acta Commercii, 1, 19-30.

Okafor, 1. C. (2014). Motivation and job satisfaction in the Nigerian public service: issues, problems, and challenges, International Journal of Liberal Arts and Social Science, 2(6), $207-$ 214.

Pepe, M. (2010). The impact of extrinsic motivational dissatisfiers on employee level of job satisfaction and commitment resulting in the intent to turnover. Journal of Business \& Economics Research (JBER), 8(9).

Petri, H., \& Govern, J. (2012). Motivation: Theory, research, and application. Cengage Learning.

Pinder, R.S. (2008). Job Satisfaction: Review and Future Considerations, Human Relations, 44, 287-307. 
Pinder, C. C. (2014). Work motivation in organizational behavior. Psychology Press.

Reilly, C.R. (1991). Organizational Behavior, Annual Review of Psychology, 427- 458.

Robbins,S. P. (2003).Organizational Behavior, $10^{\text {th }}$ ed., Prentice Hall of India: New Delhi.

Robbins, S., Judge, T. A., Millett, B., \& Boyle, M. (2013). Organizational behavior. Pearson Higher Education AU.

Rogstadius, J., Kostakos, V., Kittur, A., Smus, B., Laredo, J., \& Vukovic, M. (2011, May). An Assessment of Intrinsic and Extrinsic Motivation on Task Performance in Crowdsourcing Markets. In ICWSM.

Ryan, R. M., \& Deci, E. L. (2012). When rewards compete with nature: The undermining of intrinsic motivation and self-regulation.

Sekar, P.C.\& Narayanan (2006). "Nature and impact of work Culture in Indian Colleges: An empirical Study”, South Asian Journal of Management, 14(1), 79 - 92.

Smith, R.D. (1994).The psychology of work and human performance, (2 ${ }^{\text {nd }}$ ed.), Harper Collins College Publisher, New York.

Snell, S. (1999). Motivate Your Staff: A Self Study Workbook, London: Kogan Page Limited.

Spector, P. E. (1985). Measurement of human service staff satisfaction: Development of the Job Satisfaction Survey, American Journal of Community Psychology, 13, 693-713.

Steers, B. \& Monday, A. and Shapiro, H. (2004). Positive Psychology an Introduction, American Psychologists, 55(1), 5-14

Stringer, C., Didham, J., \& Theivananthampillai, P. (2011). Motivation, pay satisfaction, and job satisfaction of front-line employees. Qualitative Research in Accounting \& Management, 8(2), 161-179.

Sylvia, R. D., \& Hutchison, T. (1985). What makes Ms. Johnson teach? A study of teacher motivation. Human relations, 38(9), 841-856.

Thomas, K. W. \& Velthouse, B. A. (1990). Cognitive elements of empowerment: An interpretive model of intrinsic task motivation, Academy of Management Review, 15, 666681.

Trumbull, E., \& Rothstein-Fisch, C. (2011). The Intersection of Culture and Achievement Motivation. School Community Journal, 21(2), 25-53.

Uwen, S. L. M. (2000). Employee Attitudes and Job Satisfaction, Human Resource Management Review, 43, 395-407.

Vansteenkiste, M., Sierens, E., Soenens, B., Luyckx, K., \& Lens, W. (2009). Motivational profiles from a self-determination perspective: The quality of motivation matters. Journal of educational psychology, 101(3), 671.

Vidal, M. E. S., Valle, R. S., \& Aragón, B. M. I. (2007). Antecedents of repatriates' job satisfaction and its influence on turnover intentions: Evidence from Spanish repatriated managers, Journal of Business Research, 60, 1272-1281.

Watson, T. (2008). Linking employee motivation and satisfaction to the bottom line. New York: MacGraw Hill 
Willem, A., Buelens, M., \& De Jonghe, I. (2007). Impact of organizational structure on nurses' job satisfaction: A questionnaire survey. International Journal of Nursing Studies, 44(6), 1011-1020.

Wise, R. A. (2004, January). Drive, incentive, and reinforcement: the antecedents and consequences of motivation. In Nebr Symp Motiv. 50, 159-195.

Xie, J. L., \& Johns, G. (1995). Job scope and stress: Can job scope be too high?. Academy of Management Journal, 38(5), 1288-1309.

\section{Appendix}

Table A1

Variables Entered/Removed $^{\mathrm{a}}$

\begin{tabular}{|c|c|c|c|}
\hline Model & Variables Entered & Variables Removed & Method \\
\hline 1 & Compensation &. & $\begin{array}{c}\text { Stepwise (Criteria: Probability-of-F-to-enter <= } \\
.050, \text { Probability-of-F-to-remove }>=.100) .\end{array}$ \\
\hline 2 & Environment &. & $\begin{array}{c}\text { Stepwise (Criteria: Probability-of-F-to-enter }<= \\
.050, \text { Probability-of-F-to-remove }>=.100) .\end{array}$ \\
\hline 3 & Recognition &. & $\begin{array}{c}\text { Stepwise (Criteria: Probability-of-F-to-enter <= } \\
.050, \text { Probability-of-F-to-remove }>=.100) .\end{array}$ \\
\hline
\end{tabular}

a. Dependent Variable: Motivation

Table A2

Model Summary ${ }^{\mathrm{d}}$

\begin{tabular}{|c|c|c|c|c|c|c|c|c|c|}
\hline \multirow[b]{2}{*}{ Model } & \multirow[b]{2}{*}{$\mathrm{R}^{2}$} & \multirow[b]{2}{*}{$\begin{array}{l}\text { Adj- } \\
\mathrm{R}^{2}\end{array}$} & \multirow[b]{2}{*}{$\begin{array}{l}\text { SE of the } \\
\text { Estimate }\end{array}$} & \multicolumn{5}{|c|}{ Change Statistics } & \multirow[b]{2}{*}{$\begin{array}{l}\text { DW } \\
\text { Stat. }\end{array}$} \\
\hline & & & & $\mathrm{R}^{2}$ Change & F Change & df1 & df2 & $\begin{array}{l}\text { Sig. F } \\
\text { Change }\end{array}$ & \\
\hline 1 & $.443^{\mathrm{a}}$ & .436 & .78430 & .443 & 68.364 & 1 & 879 & .000 & \\
\hline 2 & $.581^{\mathrm{b}}$ & .571 & .68432 & .138 & 27.968 & 1 & 876 & .000 & \\
\hline 3 & $.616^{\mathrm{c}}$ & .602 & .65910 & .035 & 7.627 & 1 & 875 & .000 & 2.039 \\
\hline
\end{tabular}

a. Predictors: (Constant), Compensation

b. Predictors: (Constant), Compensation, Environment

c. Predictors: (Constant), Compensation, Environment, Recognition

d. Dependent Variable: Motivation 
https://ir.iba.edu.pk/businessreview/vol11/iss1/2

DOI: https://doi.org/10.54784/1990-6587.1074

Business Review - Volume 11 Number 1

January - June 2016

Table A3

ANOVA $^{\mathrm{a}}$

\begin{tabular}{|c|l|r|r|r|r|c|}
\hline \multicolumn{2}{|l|}{ Model } & Sum of Squares & \multicolumn{1}{c|}{ df } & Mean Square & F & Sig. \\
\hline \multirow{4}{*}{1} & Regression & 42.053 & 1 & 42.053 & 68.364 & $.000^{\mathrm{b}}$ \\
\cline { 2 - 8 } & Residual & 539.970 & 878 & .615 & & \\
\cline { 2 - 8 } & Total & 582.023 & 879 & & & \\
\hline \multirow{2}{*}{2} & Regression & 55.150 & 2 & 27.575 & 45.882 & $.000^{\mathrm{c}}$ \\
\cline { 2 - 8 } & Residual & 526.873 & 877 & .601 & & \\
\cline { 2 - 8 } & Total & 582.023 & 879 & & & \\
\hline \multirow{3}{*}{3} & Regression & 58.463 & 3 & 19.488 & 32.588 & $.000^{\mathrm{d}}$ \\
\cline { 2 - 8 } & Residual & 523.560 & 876 & .598 & & \\
\cline { 2 - 8 } & Total & 582.023 & 879 & & & \\
\hline
\end{tabular}

a. Dependent Variable: Motivation

b. Predictors: (Constant), Compensation

c. Predictors: (Constant), Compensation, Environment

Table A4

Coefficients

\begin{tabular}{|c|c|c|c|c|c|c|c|}
\hline \multirow{2}{*}{\multicolumn{2}{|c|}{ Model }} & \multirow{2}{*}{$\begin{array}{c}\text { Unstandardized } \\
\text { Beta }\end{array}$} & \multirow{2}{*}{$\begin{array}{c}\text { Standardized } \\
\text { Beta }\end{array}$} & \multirow[t]{2}{*}{ t-Stat } & \multirow[t]{2}{*}{ Sig. } & \multicolumn{2}{|c|}{ Collinearity Statistics } \\
\hline & & & & & & Tolerance & VIF \\
\hline 1 & (Constant) & $\begin{array}{r}.765 \\
(.084)\end{array}$ & & 9.136 & .000 & & \\
\hline & Compensation & $\begin{array}{r}.632 \\
(.076)\end{array}$ & .665 & 8.268 & .000 & 1.000 & 1.000 \\
\hline 2 & (Constant) & $\begin{array}{r}.507 \\
(.088) \\
\end{array}$ & & 5.769 & .000 & & \\
\hline & Compensation & $\begin{array}{r}.465 \\
(.074)\end{array}$ & .490 & 6.311 & .000 & .818 & 1.223 \\
\hline & Environment & $\begin{array}{r}.392 \\
(.074)\end{array}$ & .411 & 5.288 & .000 & .818 & 1.223 \\
\hline 3 & (Constant) & $\begin{array}{r}.477 \\
(.085)\end{array}$ & & 5.597 & .000 & & \\
\hline & Compensation & $\begin{array}{r}.404 \\
(.074) \\
\end{array}$ & .425 & 5.428 & .000 & .745 & 1.343 \\
\hline & Environment & $\begin{array}{r}.257 \\
(.087)\end{array}$ & .269 & 2.968 & .004 & .556 & 1.797 \\
\hline & Recognition & $\begin{array}{r}.251 \\
(.091)\end{array}$ & .259 & 2.762 & .007 & .521 & 1.919 \\
\hline
\end{tabular}

a. Dependent Variable: Motivation

b. SE are in parenthesis 
Table A5

Excluded Variables $^{\mathrm{a}}$

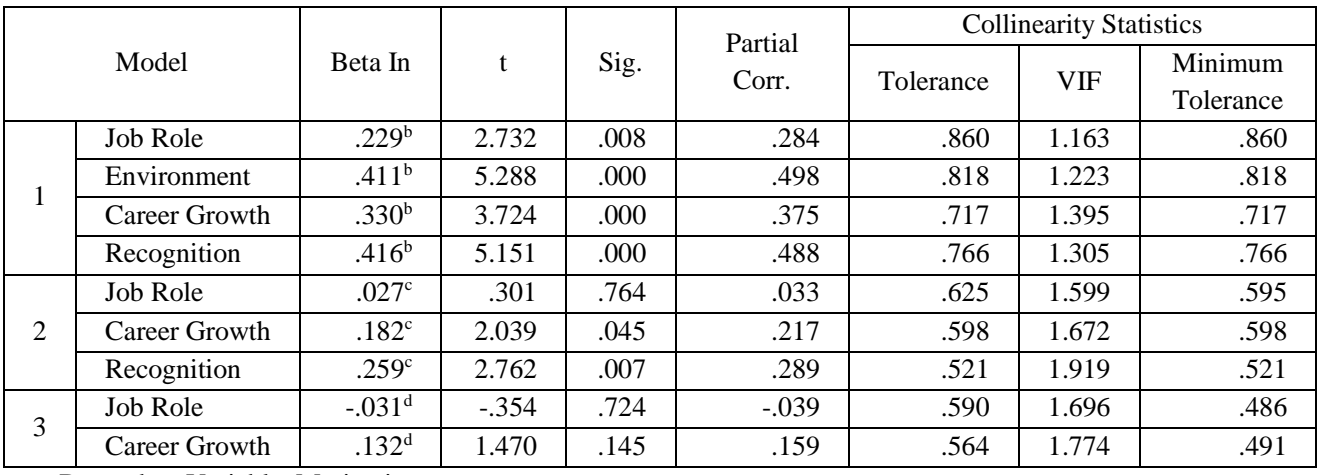

a. Dependent Variable: Motivation

b. Predictors in the Model: (Constant), Compensation

c. Predictors in the Model: (Constant), Compensation, Environment

d. Predictors in the Model: (Constant), Compensation, Environment, Recognition

Figure A1

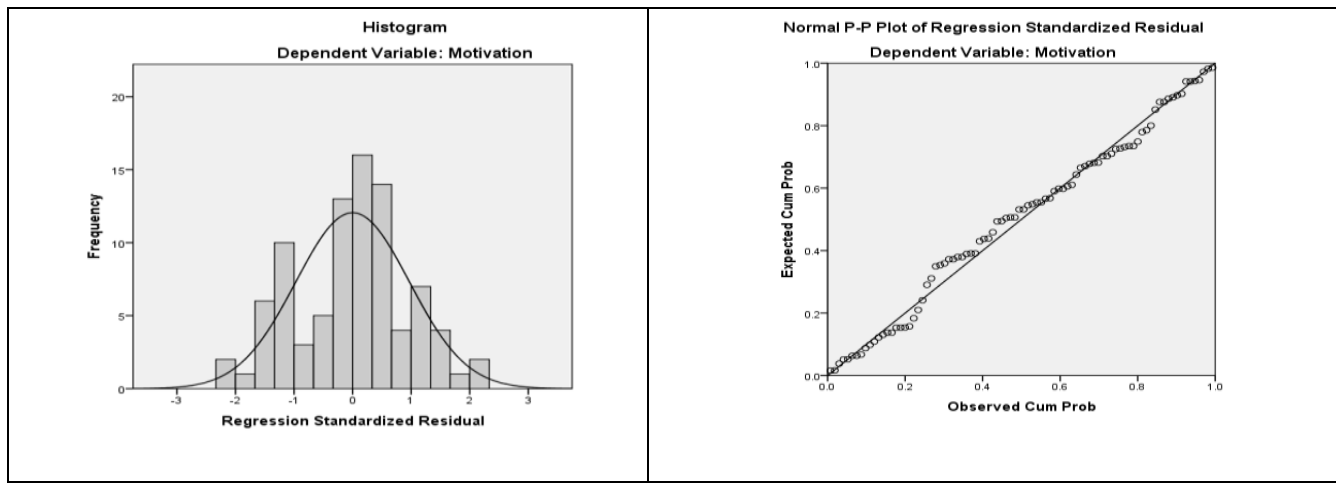

Table B1

Variables Entered/Removed ${ }^{\mathrm{a}}$

\begin{tabular}{|c|c|c|c|}
\hline Model & $\begin{array}{l}\text { Variables } \\
\text { Entered }\end{array}$ & $\begin{array}{l}\text { Variables } \\
\text { Removed }\end{array}$ & Method \\
\hline 1 & Compensation & & $\begin{array}{l}\text { Stepwise (Criteria: Probability-of-F-to-enter }<=.050 \text {, } \\
\text { Probability-of-F-to-remove }>=.100) .\end{array}$ \\
\hline 2 & Career Growth & & $\begin{array}{l}\text { Stepwise (Criteria: Probability-of-F-to-enter }<=.050 \text {, } \\
\text { Probability-of-F-to-remove }>=.100) .\end{array}$ \\
\hline 3 & Recognition & & $\begin{array}{l}\text { Stepwise (Criteria: Probability-of-F-to-enter }<=.050, \\
\text { Probability-of-F-to-remove }>=.100) .\end{array}$ \\
\hline
\end{tabular}

a. Dependent Variable: Satisfaction 
Table B2

Model Summary ${ }^{\mathrm{d}}$

\begin{tabular}{|c|c|c|c|c|c|c|c|c|c|}
\hline \multirow{2}{*}{ Model } & \multirow{2}{*}{$\mathrm{R}^{2}$} & \multirow{2}{*}{$\operatorname{Adj}-\mathrm{R}^{2}$} & \multirow{2}{*}{$\begin{array}{l}\text { SE of the } \\
\text { Estimate }\end{array}$} & \multicolumn{5}{|c|}{ Change Statistics } & \multirow{2}{*}{ DW Stat. } \\
\hline & & & & $\mathrm{R}^{2}$ Change & F Change & df1 & df2 & Sig. F Change & \\
\hline 1 & $.720^{\mathrm{a}}$ & .717 & .52623 & .720 & 221.375 & 1 & 878 & .000 & \\
\hline 2 & $.836^{\mathrm{b}}$ & .832 & .40517 & .116 & 60.073 & 1 & 876 & .000 & \\
\hline 3 & $.845^{\mathrm{c}}$ & .840 & .39575 & .009 & 5.094 & 1 & 875 & .027 & 1.855 \\
\hline
\end{tabular}

a. Predictors: (Constant), Compensation

b. Predictors: (Constant), Compensation, Career Growth

c. Predictors: (Constant), Compensation, Career Growth, Recognition

d. Dependent Variable: Satisfaction

Table B3

ANOVA

\begin{tabular}{|c|c|c|c|c|c|c|}
\hline \multicolumn{2}{|c|}{ Model } & Sum of Squares & Df & Mean Square & $\mathrm{F}$ & Sig. \\
\hline \multirow[t]{3}{*}{1} & Regression & 61.303 & 1 & 61.303 & 221.375 & $.000^{\mathrm{b}}$ \\
\hline & Residual & 243.206 & 878 & .277 & & \\
\hline & Total & 304.509 & 879 & & & \\
\hline \multirow[t]{3}{*}{2} & Regression & 71.165 & 2 & 35.583 & 133.771 & $.000^{\mathrm{c}}$ \\
\hline & Residual & 233.344 & 877 & .266 & & \\
\hline & Total & 304.509 & 879 & & & \\
\hline \multirow[t]{3}{*}{3} & Regression & 71.963 & 3 & 23.988 & 90.521 & $.000^{\mathrm{d}}$ \\
\hline & Residual & 232.546 & 876 & 0.265 & & \\
\hline & Total & 304.509 & 879 & & & \\
\hline
\end{tabular}

a. Dependent Variable: Satisfaction

b. Predictors: (Constant), Compensation Package

c. Predictors: (Constant), Compensation Package, Career Growth

d. Predictors: (Constant), Compensation Package, Career Growth, Recognition

Table B4

Coefficients $^{\mathrm{a}}$

\begin{tabular}{|c|c|c|c|c|c|c|c|c|}
\hline & \multirow[t]{2}{*}{ Model } & \multicolumn{2}{|c|}{ Unstandardized } & \multirow{2}{*}{$\begin{array}{c}\text { Standardized } \\
\text { Beta }\end{array}$} & \multirow[t]{2}{*}{$\mathrm{t}$} & \multirow[t]{2}{*}{ Sig. } & \multicolumn{2}{|c|}{$\begin{array}{l}\text { Collinearity } \\
\text { Statistics }\end{array}$} \\
\hline & & $\mathrm{B}$ & SE & & & & Tol & VIF \\
\hline \multirow[t]{2}{*}{1} & (Constant) & .367 & .056 & & 6.524 & .000 & & \\
\hline & Compensation & .763 & .051 & .849 & 14.879 & .000 & 1.000 & 1.000 \\
\hline \multirow{3}{*}{2} & (Constant) & .217 & .047 & & 4.575 & .000 & & \\
\hline & Compensation & .570 & .047 & .635 & 12.236 & .000 & .717 & 1.395 \\
\hline & Career Growth & .373 & .048 & .402 & 7.751 & .000 & .717 & 1.395 \\
\hline \multirow{4}{*}{3} & (Constant) & .183 & .049 & & 3.774 & .000 & & \\
\hline & Compensation & .542 & .047 & .603 & 11.488 & .000 & .667 & 1.499 \\
\hline & Career Growth & .325 & .052 & .351 & 6.310 & .000 & .596 & 1.678 \\
\hline & Recognition & .112 & .049 & .121 & 2.257 & .027 & .637 & 1.570 \\
\hline
\end{tabular}

a. Dependent Variable: Satisfaction 
Table B5

Excluded Variables $^{\mathrm{a}}$

\begin{tabular}{|c|c|c|c|c|c|c|c|c|}
\hline & \multirow[b]{2}{*}{ Model } & \multirow[b]{2}{*}{ Beta In } & \multirow[b]{2}{*}{$\mathrm{T}$} & \multirow[b]{2}{*}{ Sig. } & \multirow{2}{*}{$\begin{array}{l}\text { Partial } \\
\text { Corr. }\end{array}$} & \multicolumn{3}{|c|}{ Collinearity Statistics } \\
\hline & & & & & & Tolerance & VIF & Minimum \\
\hline \multirow{4}{*}{1} & Job Role & $.145^{\mathrm{b}}$ & 2.427 & .017 & .255 & .860 & 1.163 & .860 \\
\hline & Environment & $.212^{\mathrm{b}}$ & 3.584 & .001 & .362 & .818 & 1.223 & .818 \\
\hline & Career Growth & $.402^{\mathrm{b}}$ & 7.751 & .000 & 643 & .717 & 1.395 & .717 \\
\hline & Recognition & $.260^{\mathrm{b}}$ & 4.404 & .000 & .431 & .766 & 1.305 & .766 \\
\hline \multirow{3}{*}{2} & Job Role & $.058^{\mathrm{c}}$ & 1.192 & .237 & .129 & .807 & 1.239 & .673 \\
\hline & Environment & $.070^{\mathrm{c}}$ & 1.331 & .187 & .144 & .682 & 1.466 & .598 \\
\hline & Recognition & $.121^{\mathrm{c}}$ & 2.257 & .027 & .239 & .637 & 1.570 & .596 \\
\hline \multirow{2}{*}{3} & Job Role & $.017^{\mathrm{d}}$ & .320 & .750 & .035 & .672 & 1.489 & .530 \\
\hline & Environment & $.019^{\mathrm{d}}$ & .314 & .754 & .034 & .526 & 1.900 & .491 \\
\hline
\end{tabular}

a. Dependent Variable: Satisfaction

b. Predictors in the Model: (Constant), Compensation

c. Predictors in the Model: (Constant), Compensation, Career Growth

d. Predictors in the Model: (Constant), Compensation Package, Career Growth, Recognition

Figure B1

Histogram
Dependent Variable: Satisfaction

